\title{
Nemendur af erlendum uppruna: Reynsla foreldra og kennara af námi og kennslu
}

\begin{abstract}
Nemendum af erlendum uppruna hefur fjölgað mikið i íslenskum skólum. Pað kallar á að skólar bregđist við námspörfum pessa nemendahóps. Markmið pessarar greinar er að fjalla um reynslu kennara og foreldra af menntun nemenda af erlendum uppruna. Í eigindlegri rannsókn voru tekin viðtöl við prjátíu og átta grunnskólakennara um reynslu peirra af pví að kenna nemendum af erlendum uppruna og helstu áskoranir sem pví fylgja. Einnig voru tekin viðtöl við tíu erlenda foreldra um reynslu peirra af íslenskum skólum. Niðurstöđur sýna að kennarar telja sig ekki vera nægilega vel studda til pess að skilja og takast á við námsparfir nemendanna. Upplifun foreldra litast af hugmyndum peirra um skólann sem hinn hefðbundna stađ fyrir nám og íslenska skólakerfið ögrar pessum skilningi peirra. Skortur er á samvinnu og samskiptum milli forelda og kennara. Í niðurlagi er lagt til að skólar stuðli að markvissari umræðu um parfir nemenda og væntingar foreldra svo að efla megi og bæta menntun nemenda af erlendum uppruna.
\end{abstract}

Efnisorð: nemendur af erlendum uppruna, foreldrar af erlendum uppruna, fjölmenningarleg menntun, samskipti heimilis og skóla

\section{INNGANGUR}

Á síđustu tveimur áratugum hefur orđið mikil breyting á hlutfalli íbúa á Íslandi sem skilgreindir eru af Hagstofu Íslands (2016) sem erlendir ríkisborgarar. Árið 1996 var pessi hópur 1,9\% af heildarmannfjölda, árið 2006 var hlutfallið 4,6\% og árið 2016 voru 8\% íbúanna erlendir ríkisborgarar. Út frá pessari próun má nærri geta að samsetning nemenda í grunnskólum landsins hefur einnig tekið breytingum, en árið 1997 voru 377 grunnskólanemendur (0,87\%) skráđir međ erlent móđurmál en árið 2015 voru peir 3542 eđa 8,19\% nemendahópsins (Hagstofa Íslands, 2017). Breytingar sem pessar kalla á endurskođun skólastarfs sem í gegnum árin hefur tekið mið af tiltölulega einsleitum nemendahópi hvað varđar uppruna, menningu og tungumál.

Í núgildandi löggjöf um skóla á Íslandi er lögð rík áhersla á jafnrétti. Hlutverk skóla er að „.... leitast við að haga störfum sínum í sem fyllstu samræmi við stöðu og parfir nemenda og stuðla að alhliða proska, velferð og menntun hvers og eins“ (lög um 
grunnskóla nr. 91/2008). Pessi áhersla er ítrekuđ í Ađalnámskrá fyrir hvert skólastig (Mennta- og menningarmálaráđuneytið, 2012a, 2012b, 2012c). Íslensk menntastefna er byggð á hugmyndafræđinni um skóla án ađgreiningar (UNESCO, 1994), en par er lögð áhersla á að koma til móts við ólíkar parfir nemenda, hvort heldur pær eru náms- eđa félagslegar, og miđa skal skólastarf við að nemendur fái jöfn eđa jafngild tækifæri til náms. Pá er áréttað að nemendahópurinn sé fjölbreyttur og par af leiđandi séu parfir nemenda mismunandi (Mennta- og menningarmálaráđuneyti, 2012b). Prátt fyrir viđleitni til að viðurkenna fjölbreytileika innan íslenska skólakerfisins, međal annars í lögum og námskrám (Anna Kristín Sigurđardóttir, Hafdís Guđjónsdóttir og Jóhanna Karlsdóttir, 2014), hefur fjölmenningarleg hlið menntastefnunnar ekki fengið mikla athygli (Ingólfur Ásgeir Jóhannesson, 2006).

Í fræđilegri umræđu um skóla án ađgreiningar og fjölmenningarlega menntun sýna bæđi innlendar og erlendar rannsóknir að hindranir fyrir raunverulegum breytingum í átt að fjölmenningarlegum starfsháttum felast ekki síst í viðhorfi til nemenda sem purfa stuđning í námi (Banks, 2010; Hermína Gunnpórsdóttir og Ingólfur Ásgeir Jóhannesson, 2013; Slee, 2006) og pví hvađa væntingar bæđi foreldrar og kennarar hafa til peirra hvađ varđar námslega færni og árangur (De Fraja, Oliveira og Zanchi, 2010).

Í ljósi framangreindrar fjölgunar barna af erlendum uppruna í íslensku skólakerfi er leitað svara við eftirfarandi rannsóknarspurningum: Hvernig nálgast kennarar menntun barna af erlendum uppruna; og hver er upplifun og reynsla erlendra foreldra af menntun barna sinna? Í greininni eru nemendur af erlendum uppruna skilgreindir sem sá hópur nemenda sem eiga annað eða báđa foreldra fædda erlendis og eiga annað tungumál en íslensku að móðurmáli.

Í greininni verđur fjallađ um pann fræđilega bakgrunn sem hún er byggð á međ áherslu á Ísland. Rannsóknin er par næst kynnt og skýrt frá pátttakendum og rannsóknarađferđ, niðurstöður eru kynntar í fimm undirköflum og umræður um niðurstöđurnar fylgja í kjölfarið. Greininni lýkur á samantekt og ályktunum höfunda.

\section{FRÆEILEGUR BAKGRUNNUR OG SAMHENGI}

Í rannsókn sem unnin var af Sólveigu Karvelsdóttur og Hafdísi Guđjónsdóttur (2010) međal tíu kennara í tveimur íslenskum skólum benda tilvitnanir í orđ kennara til pess að nokkuð skorti á að fjölmenningarlegir kennsluhættir séu kennurum tamir: „Mig langar til að koma peim betur inn í bekkjarsamfélagið en ég veit ekki alveg hvernig ég á að fara að pví" (bls. 8). Sambærilegar áhyggjur má greina í víđtækri könnun međal grunnskólakennara á Íslandi sem gerð var af pjónustumiđstöð Miðborgar og Hlíđa í Reykjavík og náđi til 122 grunnskóla eđa 82,4\% allra grunnskóla á landinu (Hulda Karen Daníelsdóttir, Ari Klængur Jónsson og Hilma Hólmfríđur Sigurđardóttir, 2010). Niðurstöđur skýrslunnar sýndu ađ 50\% svarenda töldu pörf á pjálfun eđa fræđslu um móttöku nemenda, 75\% um gagnkvæma félagslega ađlögun og 76\% um nám og kennslu nemenda sem ekki hafa íslensku sem móđurmál. Í skýrslunni kemur einnig fram að 63\% svarenda litu á kennslu í íslensku sem öđru tungumáli sem afbrigđi af sérkennslu en skýrsluhöfundar benda á að 
í reglugerđ um nemendur með sérparfir í grunnskóla (nr. 585/2010) tekur skilgreiningin á nemendum með sérparfir ekki til erlendra nemenda (bls. 75).

Umbætur eru forsendur pess að starfshættir í anda skóla án ađgreiningar og fjölmenningarlegrar menntunar festist í sessi (Banks, 2010; Hargreaves, 2000; Kozleski, Artiles og Lacy, 2013). Í slíkum umbótum felst að litið er á fjölbreytileika nemenda sem eðlilegan hlut (OECD, 2010) en ekki vandamál. pær krefjast starfshátta í anda skóla án ađgreiningar og fjölmenningarlegrar menntunar sem einkennast af pví að nálgast nemendur og nám peirra með pað að markmiði að efla alla nemendur og koma auga á og uppræta hvers konar hindranir og útilokun sem takmarka tækifæri til náms (Kozleski o.fl., 2013; Slee, 2006).

Til pess að uppfylla kröfur um árangursríkt nám fyrir alla hefur sjónum verið beint að mikilvægi sterkrar samstarfsmenningar kennara og starfsfólks í skólum (Hargreaves, 2000) og ađ lögð sé áhersla á að fyrri pekking og reynsla nemenda fái rými í námskránni. Slík nálgun hefur verið kölluð menningarmiđuð kennsla (e. culturally responsive teaching) (Brown-Jeffy og Cooper, 2011; Gay, 2000; Ladson-Billings, 1995; Villegas og Lucas, 2002). Í menningarmiðađri kennslu er litið svo á að menning sé dýpra og flóknara fyrirbæri en almennur skilningur á uppruna (e. ethnicity), kynpætti (e. race) eđa trú (e. faith) og feli i sér víđtækan skilning á pví sem er líkt og ólíkt, sameinar og ađgreinir (e. similarity and differences) og hvernig pessir pættir móta einstaklinga sem manneskjur og nemendur. Menningarmiðuð kennsla er pví forsenda pess að allir nemendur upplifi að peir séu öruggir, velkomnir og sampykktir eins og peir eru og hvattir til pess ađ ná árangri í námi og leik.

Veigamikill páttur í pví að próa fjölmenningarlegt skólastarf án ađgreiningar er virđing fyrir fjölskyldum nemenda og fjölbreyttum bakgrunni peirra. Starfsfólk skóla parf að vera tilbúið að vinna með foreldrum með ólíkan bakgrunn og að sýna skilning á ađstæðum peirra og heimssýn (Ladson-Billings, 1995; McGee Banks, 2010). Viðhorf til uppeldis og menntunar geta til dæmis verið ólík milli menningarsvæða, svo sem hugmyndir um aga, heimanám og samband við kennara (De Fraja o.fl., 2010; DePalma, Membiela og Suárez Pazos, 2011; Ingvar Sigurgeirsson, Amalía Björnsdóttir, Gunnhildur Óskarsdóttir og Kristín Jónsdóttir, 2014, McGee Banks, 2010) sem og hugmyndir fólks um skólann sem stofnun (Foucault, 1975). Foreldrar geta veitt kennurum mikilvægar upplýsingar um börn sín og aðstođað pá við að koma auga á og skilja duldar hindranir í námi, eins og gildi og skođanir. Skortur á menningarhæfni (e. cultural competence) međal kennara og skóla (Villegas og Lucas, 2002) er einnig dæmi um hindranir sem hafa áhrif á nám nemenda en íslenskar rannsóknir gefa til kynna að ekki sé nægileg pekking innan sumra skóla á fjölmenningarlegum bakgrunni nemenda og peim áhrifum sem slíkt pekkingarleysi hefur á menntun peirra (Hanna Ragnarsdóttir, 2008; Kristín Ađalsteinsdóttir, Guðmundur Engilbertsson og Ragnheiður Gunnbjörnsdóttir, 2007; Rósa Guðbjartsdóttir og Hanna Ragnarsdóttir, 2010). Í Skýrslu Pjónustumiðstöðvar Miðborgar og Hlíđa (Hulda Karen Daníelsdóttir o.fl., 2010) kom einnig fram að pó að sumir skólar hafi sýnt framfarir í móttöku erlendra nemenda er enn um langan veg að fara pegar kemur að félagslegri aðlögun nemenda og fjölmenningarlegum kennsluháttum (bls.79). 
Í íslenskum rannsóknum par sem viðfangsefnið er fjölmenningarleg menntun hafa niðurstöđur einna helst gefið til kynna mistök skólakerfisins varđandi menntun barna af erlendum uppruna (Anh-Dao Tran, 2007; Nína V. Magnúsdóttir, 2010). Petta kemur til dæmis fram í rannsóknum sem tengjast tungumáli og tvítyngi (Anna Katarzyna Wozniczka og Robert Berman, 2011; Nichole Leigh Mosty, Samúel Lefever og Hanna Ragnarsdóttir, 2013) og ađlögun og námsupplifun innflytjendafjölskyldna (Fuhui Chen og Hanna Ragnarsdóttir, 2014; Anh-Dao Tran, 2007). Í pessum rannsóknum eru færð rök fyrir pví að nemendur af erlendum uppruna séu verr staddir en íslenskir jafnaldrar peirra (Ólöf Garđarsdóttir og Guđjón Hauksson, 2011; Póroddur Bjarnason, 2006, 2011). Í grein Hönnu Ragnarsdóttur (2016) par sem gerð er grein fyrir samnorræna rannsóknarverkefninu Learning Spaces for Inclusion and Social Justice: Success Stories from Immigrant Students and School Communities in Four Nordic Countries (LSP), sem stóð yfir árin 2013-2015 kemur í raun fram rökstuđningur fyrir pví sem kalla má mistök skólakerfisins, en hún segir:

prátt fyrir mikla grósku i rannsóknum og próun skólastarfs undanfarin ár, par sem hugmyndafræđi fjölmenningarlegrar menntunar er lögđ til grundvallar, hafa rannsóknir í ýmsum löndum bent til pess ađ innflytjendabörn séu í mörgum tilvikum jađarsett í skólum, pátttaka peirra sé takmörkuð og árangur peirra - námslegur og félagslegur - verri en annarra barna. (bls. 2-3)

Hanna Ragnarsdóttir (2016) segir jafnframt að niðurstöđur rannsókna á Norđurlöndum beri almennt að sama brunni, p.e. að námsárangur innflytjendabarna sé verri en annarra barna samkvæmt niðurstöđum PISA-rannsókna og „pau séu í mörgum tilvikum jađarsett, félagslega einangruð og njóti minni virđingar en önnur börn“ (Almar M. Halldórsson, Ragnar F. Ólafsson og Júlíus K. Björnsson, 2013, bls. 3). Í nýlegum íslenskum rannsóknum eru pó dæmi úr íslensku skólastarfi sem eru jákvæð og einkennast af faglegum viðbrögðum við pörfum pessa nemendahóps (Hanna Ragnarsdóttir og Schmidt, 2014).

Nokkrar íslenskar rannsóknir hafa verið gerđar á reynslu foreldra sem eru innflytjendur af skólakerfinu (sjá t.d. Magdalenu Zawodna, 2014), pá hafa samskipti milli erlendra foreldra og kennara verið skođuð í rannsókn Önnu Lilju Sævarsdóttur, Önnu Elísu Hreiđarsdóttur og Hermínu Gunnpórsdóttur (2013) sem og í rannsókn Birgittu B. Sigurđardóttur (2012). Í síđasttöldu rannsókninni kom í ljós að pó að færni erlendra foreldra í tjáskiptum á íslensku og jafnvel ensku líka geti stundum veriđ slök (sjá einnig: Anh-Dao Tran og Hönnu Ragnarsdóttur, 2013; Önnu Lilju Sævarsdóttur o.fl., 2013) litu bæđi kennarar og erlendir foreldrar svo á ađ samskipti peirra á milli væru jákvæð. Bakgrunnur fjölskyldna getur haft áhrif á námsupplifun barna (De Fraja o.fl. 2010; Lareau, 1987), og pátttaka foreldra í skólastarfi getur verið breytileg eftir bví hvađa menntun peir hafa og ýmsir félagslegir- og menningarlegir pættir (Bæck, 2010), til dæmis fjölskyldu- og tengslanet (Liebkind, Jasinskaja-Lahti og Solheim, 2004), hafa par áhrif líka. Til pess ađ efla pátttöku og áhrif foreldra á menntun barna sinna er pví mikilvægt ađ huga að pví hvađa væntingar og viðhorf foreldrar hafa til íslenska skólakerfisins (Jóhanna Einarsdóttir, 2008). 


\section{AĐFERĐ OG PÁTTTAKENDUR}

Pessi rannsókn er byggð á eigindlegri rannsóknarađferð (e. qualitative methodology) (Creswell, 2007) par sem viðtöl voru tekin við kennara nemenda af erlendum uppruna og foreldra sem skilgreina sig sem innflytjendur. Eigindleg rannsóknaraðferð pótti henta markmiðum rannsóknarinnar, en hún felst í pví ađ rannsaka reynslu kennara og foreldra af menntun nemenda af erlendum uppruna og reyna að skilja veruleika peirra og áskoranir í pessu samhengi (Creswell, 2007).

Viðtöl við kennara. Alls voru tekin sex rýnihópaviđtöl (Sóley S. Bender, 2013) við prjátíu og átta kennara úr sex grunnskólum í einu sveitarfélagi og eitt einstaklingsviðtal (Kvale og Brinkmann, 2009). Haft var samband við stjórnendur skólanna, peim kynnt efni rannsóknarinnar og óskað eftir liđsinni peirra við gagnasöfnun rannsóknarinnar. Skólastjórnendur voru beđnir ađ vísa á pá kennara (tilgangsúrtak) (Creswell, 2007) sem hefđu reynslu af pví að kenna nemendum af erlendum uppruna međ áherslu á nemendur sem ekki hafa íslensku sem móđurmál. Í hverjum skóla voru myndađir hópar međ ađstođ millistjórnenda, pvert á árganga, með peim kennurum sem féllu undir pessi viðmið og höfðu sampykkt pátttöku. Stærð hópanna var breytileg, međal annars vegna misjafnlega margra nemenda af erlendum uppruna í skólunum, eđa allt frá tveimur kennurum upp í ellefu. Rýnihópar (e. focus groups) urđu fyrir valinu pví að pannig gafst kostur á að deila og ræđa reynslu og upplifun kennara af viðfangsefninu (Sóley S. Bender, 2013) og rannsakendur töldu að fyllri heildarmynd af viðfangsefni rannsóknarinnar fengist með pví móti. Kennararnir voru međal annars spurđir um reynslu sína af kennslu nemenda af erlendum uppruna, hverjar peir teldu vera helstu áskoranir við kennsluna, samskipti við foreldra, samstarf við aðra kennara og skóla, stuđning frá skólayfirvöldum og símenntun. Starfsreynsla kennaranna var allt frá tveimur upp í rúm prjátíu ár og í úrtakinu voru kennarar sem kenndu eđa höfðu reynslu af kennslu í öllum bekkjum grunnskóla, frá 1. til 10. bekk. Konur voru í meirihluta og enginn kennaranna taldist vera af erlendum uppruna. Viđtölin tóku um 30-60 mínútur og fóru fram í skólum kennaranna.

Viðtöl við foreldra. Tekin voru einstaklingsviðtöl við foreldra barna af erlendum uppruna sem voru í grunnskólum sveitarfélagsins. Viðmælendur voru sex mæđur og fjórir feđur sem voru valin með snjóboltaúrtaki (Pórólfur Pórlindsson og Porlákur Karlsson, 2003). Viðmið rannsakenda um viðmælendur var að peir teldu sjálfa sig vera innflytjendur, að peir væru búsettir í sveitarfélaginu og að börn peirra stunduđu nám við grunnskóla sveitarfélagsins. Foreldrarnir voru á aldrinum 26-60 ára, bakgrunnur peirra ólíkur en allir fæddir í Evrópulöndum og allir voru í hjónabandi eđa föstu sambandi. Flestir pátttakendur voru með framhaldsmenntun og allir nema tveir peirra með háskólagráđur. Viđtölin fóru fram á kaffihúsi, í heimahúsi eđa á vinnustađ og ýmist á íslensku eđa ensku eftir óskum viðmælenda. Viðtölin stóðu að međaltali yfir í klukkustund. Pátttakendur voru spurđir út í bakgrunn sinn, menntun, búferlaflutninga og reynslu sína af skóla barna sinna á Íslandi.

Rannsakendur tóku öll viðtölin. Pau voru hljóđrituð, afrituð og síđan pemagreind í tveimur skrefum (Braun og Clarke, 2006; Vaismoradi, Turunen og Bonda, 2013). Fyrst voru viðtölin við foreldrana lesin yfir og mynstur og pemu greind, pá voru viðtölin við kennarana greind með sama hætti. pví næst var unnið með pemu frá báđum hópum, pau borin saman og greind sameiginlega í kjölfarið. Út úr peirri greiningu komu síđan sameiginleg eđa ný pemu sem unnið var međ áfram og birtast í niðurstöđum pessarar greinar. 


\section{Takmarkanir rannsóknarinnar og siðferðileg atriði}

Úrtakið í rannsókninni er lítið og viðmælendur aðeins úr einu sveitarfélagi. Markmið rannsóknarinnar var ađ rannsaka reynslu kennara og foreldra af menntun nemenda af erlendum uppruna, ekki einstaklingssjónarmið eđa einstaka skóla, í pví skyni ađ bæta megi menntun nemenda af erlendum uppruna á Íslandi. Af peim sökum var pað meðvituð ákvörđun að vitna sem minnst beint til einstakra viđmælenda heldur láta pemun sem slík fá meira vægi í niðurstöđum. Allir pátttakendur voru upplýstir um markmið rannsóknarinnar og peim var gert ljóst að niðurstöđurnar yrđu notaðar í frekari umræðu um próun menntunar pessa nemendahóps hérlendis. Rannsóknin var tilkynnt til persónuverndar. pó að úrtakið sé lítið og stađbundið teljum við að niðurstöđurnar megi nýta til að ræða og próa frekari rannsóknir og starfshætti sem tengjast nemendum af erlendum uppruna.

\section{NIĐURSTÖĐUR}

Niðurstöðurnar verđa kynntar út frá fimm pemum í samnefndum undirköflum. Pessi pemu reyndust vera sameiginleg í báđum hópum viđmælenda pó svo ađ mynstur peirra hafi verið misjafnlega pétt innan hópanna. Pemun eru: Tengsl heimilis og skóla; Skortur á aga, kröfum og heimavinnu; Fagleg pekking á fjölmenningarlegri kennslu og samstarf kennara; Jafnrétti pýđir ekki að allir purfi ađ gera og vera eins; Menningarlegur munur og menningarlega sjálfhverf námskrá.

\section{Tengsl heimilis og skóla}

Í viðtölum við kennara kom í ljós að skortur er á gagnkvæmri samvinnu og samskiptum við foreldra um menntun og skólagöngu barnanna. Kennurum pykja samskiptin erfiðari pegar báđir foreldrar eru af erlendum uppruna. Peir tóku dæmi af foreldrafundum par sem augljóst var ađ foreldrarnir skildu ekki bađ sem rætt var um. Í sumum tilvikum voru notađir túlkar, en kennurum fannst pau viðtöl vera yfirborđskennd par sem ekki gafst nægilegur tími til að kafa djúpt í umræđuefnið. Allir foreldrar fá reglulega fréttabréf sent heim í tölvupósti par sem fjallað er um skólastarfið og vinnu nemenda. Kennarar bentu hins vegar á að pessi samskiptamáti væri einhliða og ef foreldrar ættu í erfiðleikum með að skilja íslensku nýttist petta peim ekki til að átta sig á skólastarfinu og pátttöku barns síns í pví. Einn kennari tók sem dæmi að hann hefði fengið leyfi skólastjóra til að pýđa fréttabréf skólans, en sökum kostnađar hefđi hann purft ađ stytta textann:

pað kostađi skólann alveg ofbođslega mikið og pađ pótti mér verst að pað var pressa frá stjórnendum að hafa petta hnitmiðað, bara pað sem virkilega parf að segja, annars hefði ég getað sent peim miklu meira ... og svo sögđu pau [foreldrarnir] við mig seinna pegar ég hitti pau ađ pau hlökkuđu alltaf svo til ađ fá pennan póst frá mér ... ađ opna hann á kvöldin ... en mađur purfti að spara svolítið bréfin ... mađur sér petta alveg fyrir sér, sko, petta eru kannski einu upplýsingarnar sem pú færð yfir barnið pitt í skólanum.

Umræða kennaranna gaf til kynna að almennt skorti á samskipti milli foreldra og kennara og pað væri ekki endilega háð getu foreldranna til að að tjá sig á íslensku. 
Í máli foreldranna mátti einnig greina merki um ađ peir pekktu illa til starfshátta skólanna. Ein mæđranna svarađi pegar hún var spurđ hvađ börnin hennar gerđu í skólanum: „Ég veit pađ ekki. ... Ég veit reyndar ekki hvernig peir kenna í skólanum.“ Orđ í máli foreldrana sem tákna óvissu, líkt og „ég er ekki viss“, „kannski“ voru algeng og benda til pess að peir átti sig ekki á starfsháttum skólanna og peim væntingum sem gerđar eru til barna peirra. Prátt fyrir pað höfðu flestir foreldranna sterkar skođanir á skólum barna sinna og margir lýstu til dæmis peirri skoðun að íslensk menntastefna og kennsluhættir væru með svipuđum hætti og íslenskir uppeldishættir, sem peir skilgreindu sem frjálslynda.

Pó ađ viđtölin við foreldrana séu ađeins tíu má samt sem áđur greina pá í prjá flokka eftir lýsingum peirra á samskiptum sínum við skólana og pátttöku í skólastarfinu: 1) peir sem eiga frumkvæði og taka virkan pátt; 2) peir sem hafa beint samband við kennara og 3) peir sem eiga hlutlaus samskipti.

Foreldrar sem sýna frumkvæði og taka taka virkan pátt eiga gagnkvæm samskipti við skólann, til dæmis með pví að ganga í foreldrafélagið. Ein móđir gekk í foreldrafélagið „til að kynnast skólaumhverfinu. ... Ef ég var ósátt við eitthvað pá gat ég nefnt pađ á fundum.“

Dæmi voru um foreldra sem eiga bein samskipti við kennara eđa starfsfólk ef peir hafa áhyggjur eđa spurningar vegna barna sinna. Ein móðir var til dæmis óánægð með að purfa að kvitta á hverjum degi á blað um að barnið hefđi lesið upphátt fyrir hana. Hún vildi leyfa barninu sjálfu að skrifa og kvitta á blađið og óskađi eftir bví við kennarann. í fyrstu mætti hún mótstöðu, og kennarinn útskýrði að pessu væri ekki hægt að breyta. petta breyttist hins vegar með tímanum og kennarinn leyfði barninu að staðfesta sjálft heimalesturinn og móðirin var mjög ánægð með niðurstöðuna.

Algengasta samskiptaform foreldranna er hins vegar hlutlaus nálgun að samskiptum, og lýsir sér til dæmis pannig að foreldrar mæta á fundi og ađra viđburđi tengda skólanum en eru ekki opinskáir varđandi vandamál sín eđa áhyggjur og leita annarra leiða til að nálgast pær upplýsingar sem peir parfnast. Ein móđir útskýrđi til dæmis hvernig hún nýtti netið til að finna upplýsingar sem hún hafđi ekki skilið. Til að komast hjá pví að eiga bein samskipti við starfsfólk kaus hún ađ nálgast upplýsingar á heimasíđu skólans. Pótt hún hefđi pó nokkrar áhyggjur af námi barnsins, pá talađi hún aldrei við kennara eđa starfsmenn skólans og réttlætti pessa ákvörđun međ pví ađ segja ađ sem útlendingur hlyti hún að verða að laga sig að háttum og venjum skólans:

par sem að ég er hérna, og ađrir foreldrar virđast ánægđir međ petta, pannig ... Ég parf að ađlagast af pví ađ ég er frá öđru landi. Ég er önnur menning, ég get ekki breytt kerfinu hér ein.

Skólum er skylt samkvæmt lögum (lög um grunnskóla nr. 91/2008) að hafa móttökuáætlun fyrir nemendur með annað móðurmál en íslensku. Kennarar voru ekki spurđir beint út í pessa áætlun eđa hvort og hvernig hún væri notuđ. Hins vegar kom í ljós, pegar gögnin voru greind, ađ móttökuáætlunina bar aldrei á góma í umræðum kennara fyrir utan eitt skipti par sem greint var frá pví ađ til stæđi ađ endurskođa móttökuáætlun skólans. Ekki er pví ljóst hvort móttökuáætlanir eru óvirkar sem stuđningur eđa verkfæri í starfi kennara og samskiptum við nemendur og foreldra eđa svo sjálfsagður hlutur að kennarar sjá ekki ástæðu til að nefna pær í viðtölunum. Foreldrar voru spurđir út í móttökuáætlunina en enginn kannađist við slíka áætlun og peir vissu ekki betur en að börnin peirra fengju sömu menntun og íslensk börn, fyrir utan aukaađstoð með íslenskuna. 


\section{Skortur á aga, kröfum og heimavinnu}

Foreldrunum finnst skorta aga í skólunum og peir líta á pađ sem merki um óreiðu og telja að pað sé ekki til pess fallið að stuðla að virku námi. Peir upplifa skólastofuna sem skipulagslausa heild par sem nemendur hreyfa sig ađ vild; fara út úr stofunni, koma til baka, borđa, drekka og svo framvegis.

prátt fyrir lýsingar á agaleysi eru dæmi um ađ peim pyki skólastofan virka eins og „lítið lýðræđisríki“, eins og eitt foreldri orđaði pað, par sem börn sem hafa fengið nóg „geta lagst niður með teppi og slappað af“ eða „geta farið afsíðis til að einbeita sér að lestri“. Foreldrar eru undrandi á pví að börnunum sé leyft að koma og fara úr skólastofum eins og peim hentar. Peir eiga pví ađ venjast frá heimalöndum sínum að börnin sitji kyrr pangað til kennarinn gefur peim leyfi til að fara úr sætum sínum. Pessar stífu setur og hlýđni við kennarann er að peirra mati merki um áhuga og athygli nemandans. Annað dæmi um skort á aga sem foreldrarnir nefna er ađ börnin fá ekki heimavinnu í grunnskólanum. í peirra huga er heimavinna skýrt merki um að kennarinn og skólinn geri kröfur til barnsins og trygging fyrir pví að nemendur finni að peir purfi að hafa fyrir náminu.

Foreldrar bera kennurum jafnan vel söguna en peir eru ekki endilega hrifnir af frjálslegu umhverfi og vinsamlegu viðmóti peirra. Ein móđirin sagđist til dæmis vera mótfallin pví að dóttur hennar væru falin auðveldari verkefni en öđrum vegna pess að hún stæði ekki jafnfætis jafnöldrum sínum og sagđi:

Hún lærir ekki neitt ef hún parf ekki að reyna. Ég vil bara láta hana reyna, en peir [kennararnir] vilja pað ekki pví peir vilja ekki gera hlutina erfiða fyrir hana. Ég held að ef pað væri örlítil meiri pressa pá myndi hún læra meira.

Petta sjónarmið kom ítrekað fram í viðtölunum við foreldrana, en peir telja flestir að of litlar kröfur til barnanna hafi neikvæð áhrif á nám peirra í framtíđinni međ peim hætti að pau verđi illa undirbúin fyrir frekara nám, og námshvatinn sé lítill. Ein móđir sagđi: „Hún náđi að komast í gegn ... en henni fannst erfitt að taka námið alvarlega. Hún ákvað að hana langađi ekki í háskóla og fór í verknám." Tvær mæđur nefndu í viđtölunum ađ pær kenndu börnum sínum heima. Ástæđurnar fyrir pví voru pó ólíkar, önnur gerđi pađ svo að barnið hennar næđi sama getustigi og jafnaldrar pess í heimalandinu, hin vegna pess að íslenska námskráin er of sjálfhverf (of mikil áhersla á Ísland og nærumhverfið) að hennar mati og hana langar til ađ fræða barnið sitt um heimalandið.

Áhyggjur foreldra af agaleysi og litlum kröfum tengjast peirri trú ađ árangur skili sér með mikilli fyrirhöfn og að prýstingur hvetji til árangurs. Peir upplifa samt sem áđur velvilja kennaranna: „Petta stangast svolítið á, ég tel að kennarar vilji að nemendum gangi vel en um leið vilja peir ekki prýsta of mikið á pá.“

\section{Fagleg pekking á fjölmenningarlegri kennslu og samstarf kennara}

Meirihluti kennaranna telur ađ málefnum nemenda af erlendum uppruna sé lítill gaumur gefinn í kennaranáminu. Pessa skođun mátti líka heyra hjá peim sem nýlega hafa útskrifast úr kennaranámi. Örfáir nefndu að eitthvað hefđi verið fjallað um fjölmenningu í framhaldsnáminu en töldu að mjög lítið hefđi verið kennt um tvítyngi og kennsluađferđir fyrir nemendur sem ekki hafa íslensku sem móđurmál. pađ sama var uppi á teningnum 
pegar rætt var um símenntun kennara, og meirihluti sagđi að ekki hefðu verið í bođi námskeið sem tengdust málefnum nemenda af erlendum uppruna. Einn kennari sagđi: „Рað hefur kannski einhvern tímann verið bođið upp á námskeið, ég bara man pađ ekki, eđa ég hef ekki sótt pau." í máli eins kennara kom fram ađ ýmislegt væri í bođi, pađ pyrfti bara að bera sig eftir pví. Umræðan í viđtölunum bar pess pó merki að petta málefni hefđi ekki forgang, hvorki hjá kennurum né stjórnendum.

Kennarar voru spurđir út í samstarf peirra á milli innan skóla og milli skóla, t.d. međ pví að skiptast á reynslusögum og ađferđum sem hafa gagnast vel. Að peirra mati er lítið um slíkt samráđ og samstarf milli skóla og í sumum skólanna einnig mjög lítið innanhússsamráđ eđa -samstarf. Hér er dæmi úr umræđunni: Spyrjandi: „Nú eruð pið a.m.k. fimm sem eruð með nemendur af erlendum uppruna í bekknum ykkar, eruð pið mikið að leita hvert til annars?“ Fjórir svöruðu neitandi og einn svarađi: „Ég hef bara leitað til [kennsluráđgjafans], pað er frekar að mađur geri pađ."

Í samræđu kennara um innra samstarf kom í ljós að oft er brugđist á ólíkan hátt við námspörfum nemenda. Kennarar tóku dæmi um dönskukennslu og tvo nemendur af erlendum uppruna, hvorn í sínum bekknum í sama skólanum, sem áttu í erfiðleikum međ að læra dönsku ${ }^{1}$. Annar nemandinn var látinn halda áfram að læra dönsku međ miklum stuðningi en litlum árangri en hinum nemandanum var bođið að sleppa dönskunni og einbeita sér að pví að læra íslensku í stađinn. pađ kom kennara fyrri nemandans í opna skjöldu að sá seinni skyldi fá að skipta dönskunni út fyrir íslensku.

\section{Jafnrétti pýðir ekki að̃ allir purfi að gera og vera eins}

Foreldrum fannst hugmyndin um skóla án ađgreiningar vissulega heillandi en sumir létu í ljós efa um hentugleika hennar og árangur:

Hvernig geta börn lært á áhrifaríkan máta pegar sum eru fljótari en önnur, eđa pegar pau eru öll að vinna mismunandi verkefni sem byggist á getustigi peirra? Hvernig er hægt ađ innleiđa jafnrétti í skólastofum pegar geta nemenda er ekki jöfn?

Einn fađir lýsti peirri skođun sinni að pað væri raunverulegt vandamál að „hafa erlendu börnin undir sama paki og pau íslensku“. Honum fannst að sökum peirrar ríku áherslu sem lögð er á jafnrétti í íslenskum skólum óttuðust kennarar að vera sakađir um mismunun með pví ađ veita sumum börnum sérstaka međferð. petta leiđi til pess ađ kennarar veiti pessum mismun ekki athygli og vinni ekki með hann og afleiðingin sé sú að börnin verði óörugg og upplifi meiri brennimerkingu en ella. Hann telur kennara vera óundirbúna til að takast á við börn sem eru öđruvísi og að menningarmunur sé ekki viđurkenndur í skólum og kennarar átti sig hreinlega ekki á pví hvernig hann geti birst. Hann kemur með dæmi til að útskýra hvađ hann á við:

Sem dæmi, pá erum við ekki međ sundkennslu [í mínu heimalandi]. Börn sem hafa verið hér lengi eru miklu betri í sundi. peir setja alla saman í hóp og börn geta gert grín ađ bví.... pau fóru aldrei í sundkennslu og hafa aldrei afklæđst fyrir framan önnur börn. Petta er meira menningarlegur munur. pau eru sett hingað og kennarar neyða pau til að gera petta. Fara í sturtu, og pau gráta og geta ekki gert pað. pú gætir sagt, allt í lagi, reyndu að vera opnari, en pað tekur tíma. ... Kennararnir halda að peir séu að hjálpa peim en eru í raun að gera hið gagnstæða. 
Fađirinn sem talar í dæminu hér að ofan rakti viðbrögð kennaranna til pess sem hann kallaði „hina íslensku bjartsýni“ og pess viðhorfs að taka hlutina ekki of alvarlega. Hann taldi að getuleysi kennara til að skilja og viðurkenna venjur barna af erlendum uppruna stafađi af skorti á pekkingu á ólíku menningarlegu umhverfi. petta væri einnig tengt peirri sterku trú ađ öll börn séu jöfn og að líta beri á pau sem jafningja en vegna pess að kennarar væru ekki pjálfađir til pess að vinna með fjölbreytileikann leiddi bað til pess að honum væri ekki gaumur gefinn. Pess vegna væri komið eins fram við öll börn, en pað væri alls ekki pað sama og jafnrétti.

\section{Menningarlegur munur og menningarlega sjálfhverf námskrá}

Í umræðu foreldra um pað hvernig skólinn ætti að vera kemur fram að peir sjá fyrir sér stað par sem jafnvægi ríkir milli skilnings og aga, frelsis og stjórnunar og sjálfstæđis og virđingar. Skortur á aga (engar reglur eđa ekki nægilega margar og ekkert skipulag) er áberandi áhyggjuefni foreldra í viđtölunum pví peir vænta pess ađ skólinn kenni börnum peirra að fylgja reglum, sem að mati margra peirra er nauðsynlegur undirbúningur fyrir fullorđinsárin.

Viðhorf og mat foreldranna á íslenska skólanum er ekki byggt á íslenskum forsendum skólastarfs heldur pví hvernig skólakerfinu er háttađ í peirra eigin heimalandi. peir meta skólana á grundvelli pess samanburđar og gagnrýna pađ sem peir telja vera einhliđa nálgun á menntun, međ mikilli áherslu á einungis lestur, ásamt pví að einblína svo til eingöngu á Ísland í námskránni. Læsi gegnir mikilvægu hlutverki i íslenskri sögu og menningu og er ein meginstoð íslenska menntakerfisins (Mennta- og menningarmálaráđuneyti, 2012a, 2012b, 2012c). Heimanám í íslenskum grunnskólum hefur lengi einkennst af pví ađ nemendur á yngri stigum lesi á hverjum degi. Flestum foreldrunum finnst áherslan á lestur og bókmenntir ekki stuðla að fjölbreyttri menntastefnu og velta fyrir sér hvers vegna slík áhersla er lögð á lestur en lítið annað í heimavinnu. Margir lýsa einnig áhyggjum af námskránni sem peim pykir landfræđilega og menningarlega sjálfhverf og lýsa skorti á pekkingu á Evrópu og öđrum stöđum í heiminum. Petta á einna helst við pá sem eiga sér pann draum eđa áforma ađ fara aftur til síns heimalands:

Sem dæmi, pá er peim ekkert kennt um Pólland í sögu en mikið um Norđurlöndin. Hann segir að pau séu einungis frædd um Ísland, ekkert um önnur lönd. Í pólskum námsbókum færðu einnig fræđslu um Bretland, Kína, Japan og allt.

Móđirin sem hér er vitnađ til vill bæta barninu sínu petta upp með aukakennslu heima og í einn til tvo tíma á dag kennir hún pví barninu um heimaland sitt, Pólland, og annađ skylt efni. Foreldrar nefndu einnig að peir hefðu búist við að íslenskir nemendur stæðu námslega jafnfætis nemendum í öđrum Evrópulöndum en töldu að íslenskir nemendur væru allt ađ tveimur árum á eftir nemendum í heimalandi peirra.

Margt af pví sem foreldrar telja neikvætt i íslenskum skólum getur að peirra mati einnig verið jákvætt. Í pessu sambandi nefna peir lítinn námslegan prýsting og álag á nemendur og tengja pađ beint vellíđan barna sinna í skólaumhverfinu. Peir upplifa ađ skólinn og kennararnir séu mjög manneskjulegir og virđi parfir barnanna. Pó að erlendu foreldrarnir séu gagnrýnir á grunnskólana, pá segja peir allir að börnin peirra hafi gaman af pví að 
vera í skólanum og að peim líđi vel par. Skođun barnanna á skólanum og pađ hvernig pau upplifa hann skiptir foreldrana miklu máli, og peir kunna að meta pađ frelsi og sjálfstæđi sem börnunum er veitt. ’að auki tilfinningu peirra fyrir frelsi og „ýti undir sköpunarkraft“.

\section{UMREĐA}

Við höfum kosið að draga fram prjá pætti sem við teljum sýna megindrættina í niðurstöðum pessarar rannsóknar. Í fyrsta lagi verđur fjallað um skort á gagnkvæmu samstarfi og samtali milli heimilis og skóla, í öđru lagi hæfni kennara til ađ vinna međ menningarmun í skólastarfi og í priđja lagi ólíkar hugmyndir kennara og foreldra um skólann sem stofnun.

\section{Skortur á gagnkvæmu samstarfi og samtali milli heimilis og skóla}

Í raun má segja ađ niđurstöđurnar hverfist ađ stærstum hluta um pá stöđu að töluvert skortir á skipulag og stefnu í samstarfi og samskiptum milli heimila nemendanna og skólanna. Ekkert í máli foreldra og kennara bendir til pess að samskipti séu erfið eđa neikvæð, pvert á móti má greina velvilja og vinsemd á báđa bóga. Foreldrar sem flytja í nýtt land par sem við tekur nýtt tungumál, ný menning og nýjar og jafnvel framandi áherslur í skólastarfi purfa aðstoð við að skilja og fóta sig í slíkum aðstæðum. pað er hlutverk skólanna að ađstođa foreldra í pessu verkefni. Í Ađalnámskrá grunnskóla (Mennta- og menningarmálaráđuneyti, 2012b) í kafla um samstarf heimila og skóla (bls. 45) segir ađ upplýsingagjöf milli heimila og skóla og samrád kennara og foreldra um nám og kennslu sé mikilvæg forsenda fyrir árangursríku skólastarfi. par segir einnig ađ skólar beri ábyrgð á pví að slíkt samstarf komist á og pví sé viđhaldið alla skólagönguna. Af gögnum okkar er ljóst ađ misbrestur er á markvissu samráđi og einfaldlega samtali milli heimilis og skóla um markmið nemenda af erlendum uppruna í námi og væntingar peirra og foreldra peirra til náms og kennslu. Við teljum að afleiđingar pessa misbrests geti skýrt, að hluta til, af hverju foreldrar eiga erfitt með að skilja skólastarfið, eins og niðurstöđur pessarar rannsóknar benda til. Í fræđilegri umræđu um fjölmenningarlegt skólastarf (McGee Banks, 2010) eru samskipti talin lykilatriđi í ađ koma á fjölmenningarlegum starfsháttum og vegur frumkvæði skóla par mest við að koma á samskiptum við foreldra, styđja pá og leiđbeina peim við að átta sig á námsumhverfinu. Hluti af pessari ábyrgð er að ræđa við foreldra og nemendur um pær væntingar sem peir hafa til námsins, en međ slíkum samtölum geta foreldrar einnig öđlast pekkingu og skilning á starfsemi skólans. Við teljum að lýsingar kennaranna á ýmsum formum samskipta við foreldrana (foreldraviðtöl, fréttabréf, túlkar), og ófullnægjandi afrakstri slíkra samskipta að peirra mati, sýni dæmi um samskipti sem skili ekki tilætluðum árangri. Pessi túlkun á stođ í reynslu foreldranna sem lýsa óvissu um pađ hvernig nám barnanna fer fram og skilningsleysi á íslenska skólakerfinu.

Ýmsar erlendar rannsóknir hafa sýnt fram á ađ foreldrar međ framhaldsmenntun eru líklegri til að taka pátt í samstarfi heimilis og skóla og tilhneigingin og getan til að ljá áhyggjum sínum rödd er ríkari međal meira menntađra foreldra (Bæck, 2010). Í okkar rannsókn voru flestir foreldranna međ háskólagráđu en par sem úrtakið var lítið voru niðurstöđur ekki greindar eftir menntun foreldranna. En prátt fyrir hátt menntunarstig peirra sýna niđurstöđurnar verulegan skort á samskiptum. 
Heimanám bar oft á góma í viđtölunum og foreldrar töldu almennt ađ börnin fengju of lítið heimanám og ađ lítið sem ekkert heimanám bæri vott um litlar kröfur til nemenda af hálfu skólans. Í rannsókn Bæck (2010), sem fjallar um viðhorf norskra kennara til samstarfs heimilis og skóla, kom fram að kennarar vildu ekki að foreldrar kæmu of mikið að heimanámi nemenda og peir forđuđust að setja nemendum fyrir heimanám sem krafđist ađstođar foreldra. Í okkar rannsókn var ekki kannađ hvort nemendur af erlendum uppruna fá minna heimanám en ađrir nemendur en pađ er pó skođun foreldranna ađ heimanám sé of lítið og ekki nógu krefjandi. Í íslenskum skólum hefur próun heimanáms verið sú ađ stilla pví í hóf, pó svo ađ alltaf sé eitthvert heimanám á dagskrá, en áhersla er pess í stað lögð á að nemendur sinni náminu betur á skólatíma. Lestrarpjálfun er pađ form heimanáms sem almennt hefur haft forgang sem heimanámsverkefni (Ingvar Sigurgeirsson o.fl., 2014). pað er til dæmis hugsanlegt að foreldrar nemenda af erlendum uppruna viti ekki af pessum áherslum, ekki síst ef peir hafa ekki verið fræddir sérstaklega um pær.

Niðurstöđur okkar sýna að algengasta samskiptaform foreldranna er hlutlaus nálgun að samstarfi, pað er að foreldrar tjá sig ekki opinskátt um vandamál eđa áhyggjur sem tengjast námi og kennslu barna peirra. Foreldrar eru mikilvægur tengiliđur skólanna við nemendur og pví er mikilvægt að skólar hvetji foreldra til pess að eiga virkt og gagnkvæmt samstarf um nám nemenda.

\section{Hæfni kennara til að̃ vinna með̃ menningarmun í skólastarfi}

Samhljómur er í máli kennaranna um pađ ađ málefnum nemenda af erlendum uppruna sé lítill gaumur gefinn, hvort sem er í kennaranámi eđa í símenntun kennara. Niđurstöđurnar gefa til kynna að lítil sem engin formleg og samræmd vinna eigi sér stað innan skólanna par sem málefni pessa nemendahóps eru í brennidepli. Myndin sem blasir við er af velviljuðum kennurum sem reyna upp á eigin spýtur að sinna pörfum nemendanna eftir bestu getu en eru jafnframt međvitađir um að ekki er nóg að gert. Málefni nemenda af erlendum uppruna sem purfa viđbótarstuđning í námi eru helst í umsjá sérkennara eđa utanađkomandi kennara sem kennir eingöngu íslensku, en sú skipan hefur víða verið gagnrýnd (OECD, 2010) og pykir ekki til pess fallin að efla hinn almenna kennara í starfi sínu með nemendum af erlendum uppruna.

Kennsla pessa nemendahóps snýr ekki eingöngu að pví að læra tungumálið og að læra á íslensku, ekki parf síđur að taka mið af menningartengdum páttum (Gay, 2000). Pað voru einmitt slíkir pættir sem foreldrarnir töldu að væri helst áfátt í skólum barna sinna. peir töldu að lítið sem ekkert væri unnið með menningarlegan bakgrunn barnanna og í stað pess að viðurkenna og vinna með fjölbreytileika nemenda væri ofuráhersla á að eitt og hið sama gilti fyrir alla. Að peirra mati hafa kennarar ekki pekkingu til pess að vinna með menningartengda pætti og sampætta pá námskránni og afleiđingin verđi sú að börnin upplifi óöryggi og jafnvel stimplun. Í fjölmenningarlegri kennslufræđi (Gay, 2000, 2002; Villegas og Lucas, 2002) er lögđ áhersla á ađ menningarlegur bakgrunnur, pekking og reynsla nemenda sé samofin námskránni og sé hluti af námsupplifun nemenda í skólanum. Slík nemendamiðuð umgjörð er ekki ađeins viðurkenning á sérstöđu hvers nemanda heldur er lögð sérstök rækt við hana í peim tilgangi að greiđa fyrir árangursríkum aðstæðum til náms. Рað er hins vegar ekki sjálfgefið að kennarar búi yfir pessari hæfni 
og pví parf að leggja grunn að henni í kennaranámi (OECD, 2010) og viðhalda henni með símenntun sem liđ í faglegri starfspróun innan skóla og pvert á skólastig. Hargreaves (2000) hefur bent á ađ fagleg starfspróun verđi ekki einungis međ pví að leita pekkingar og stuðnings utan frá, pađ verđi oftar en ekki meiri árangur og hún viðhaldist frekar ef hún kemur að innan frá samstarfsađilum. Niðurstöđur pessarar rannsóknar benda til pess að innan skólanna sé ekki nægilegur hvati né skipulagđur farvegur til ađ vinna með menningartengda pætti í uppruna og bakgrunni nemenda og tengja pá námi peirra.

\section{Ólíkar hugmyndir kennara og foreldra um skólann sem stofnun}

Í niðurstöðunum kemur vel fram að kennarar og foreldrar hafa ólíkar hugmyndir um hlutverk skólans sem menntastofnunar. Augljósasta dæmið er viðhorf til aga og heimanáms, en foreldrunum finnst agaleysi ríkja í skólunum og að litlar sem engar kröfur um heimanám séu merki um litlar væntingar til nemenda. Hugmyndir um aga tengjast gjarnan viðhorfi til hreyfanleika og taka má dæmi um myndlíkingu af hermanni til pess að skilja betur upplifun foreldranna. Algert hreyfingarleysi hermannsins er merki um hlýðni, og ef honum tekst ekki að vera kyrr er pað merki um skort á aga (DePalma o.fl., 2011) pví hreyfing og óreiða fylgjast að (Foucault, 1975). Í tilfelli foreldranna má pví segja að hreyfing og pað að nemendur stjórni henni sjálfir stríđi gegn skilningi foreldranna á skólanum sem skipulögðum og öguðum stað (Foucault, 1975). Í viðtölunum við foreldrana nota peir gjarnan orð eins og „prýsta”, „pressa” og svipuð orð til að útskýra að pað megi vel leggja meira á börnin í náminu. Við teljum að viðhorf peirra til náms megi tengja peirri hugmynd að árangur náist ekki án fyrirhafnar (De Fraja o.fl., 2010) og pess að leggja mikið á sig. Foreldrarnir taka gjarnan dæmi af kröfum og viđmiðum frá eigin heimalandi, par sem kröfur til nemenda eru meiri ađ peirra mati, til dæmis um námsárangur. Í alpjóđlegum samanburði, til dæmis ef niðurstöður PISA-könnunarinnar² eru skoðaðar, kemur fram að námsárangur íslenskra 15 ára nemenda er talsvert undir međaltali OECD-ríkjanna. Pað kemur hins vegar einnig fram í niđurstöđunum frá 2013 (Almar Halldórsson o.fl., 2013) að nemendur í íslenskum skólum skora mun hærra en áđur hvađ varđar jákvæđan bekkjaranda og viðhorf nemenda til náms og til kennara sinna. pær niðurstöđur benda til pess að nemendum líđi ađ jafnađi vel i íslenskum skólum og er pađ í ágætu samræmi við jákvæđar lýsingar foreldra á líđan barna sinna í skólunum.

Önnur niðurstaða sem vert er að ítreka í pessari umfjöllun er ólíkur skilningur foreldra og kennara á menntastefnunni skóli án ađgreiningar og peirri áherslu ađ mæta nemendum á peirra eigin forsendum (Mennta- og menningarmálaráđuneytið, 2012b). Foreldrar sögðu pannig að peim fyndist skrýtið að nemendum af ólíku getustigi væri kennt saman og einnig að nemendur af erlendum uppruna og íslenskum lærðu saman. Hér vísa foreldrar til eigin menningar par sem áherslur eru ađrar en tíđkast á íslenskum skólum, en í ljósi fyrri niđurstađna um skort á samskiptum milli heimilis og skóla má einnig gera ráđ fyrir að foreldrar skilji ekki starfshætti skólanna og pær áherslur sem lagđar eru til grundvallar í námi og kennslu. 


\section{SAMANTEKT OG ÁLYKTANIR}

Niðurstöđur pessarar rannsóknar benda til pess að íslenska skólakerfið ögri skilningi erlendu foreldranna á skólanum sem stað fyrir hefðbundið nám. Mat foreldranna á námsumhverfi barna sinna tekur mið af skólakerfinu í peirra eigin landi og peim kröfum sem peir eiga að venjast pađan. Við teljum að međ pví að efla samstarf heimilis og skóla međ markvissu samtali um væntingar og markmið til námsins gætu foreldrar öđlast betri skilning á starfsemi skólanna og kennarar á sama hátt lært betur ađ skilja kröfur og væntingar foreldranna. pá sýnist okkur að lítið sem ekkert sé gert til pess að styðja kennara við að skilja og skipuleggja fjölmenningarlega menntun.

Í upphafi var lagt upp međ eftirfarandi tvær rannsóknarspurningar: Hvernig nálgast kennarar menntun barna af erlendum uppruna og hver er upplifun og reynsla erlendra foreldra af menntun barna sinna? Niðurstöður gefa til kynna að kennarar nálgist menntun pessa nemendahóps á mjög tilviljunarkenndan og misvísandi hátt og að peir hafi veikan fræđilegan grunn til að byggja á í kennslu sinni. Foreldrar upplifa að ekki séu gerđar nægilegar námslegar kröfur til barna peirra og óttast að pađ hafi áhrif á möguleika peirra í framhaldsnámi. Kennarar hafa einnig áhyggjur af pví ađ pessi nemendahópur standi höllum fæti pegar komið er í framhaldsskóla. Bæđi foreldrar og kennarar átta sig á pessari stöđu og gera sér grein fyrir bví að núverandi tilhögun muni hugsanlega takmarka námstækifæri pessara barna í framtíđinni. í pví ljósi teljum við að pörf sé á frekari rannsóknum til ađ skilja betur hvađa leiđir og ađferđir eru líklegri til árangurs en pær sem nú eru notađar.

\section{ATHUGASEMDIR}

1 Danska er skyldufag í íslenskum skólum og í ađalnámskrá (Mennta- og menningarmálaráđuneyti, 2012b) er tilgangurinn sagður vera: „að viðhalda og styrkja tengslin við Norđurlandapjóđirnar og stuðla að pví að Íslendingar eigi greiða leið að sameiginlegum markađi menntunar og atvinnu á öllum Norđurlöndunum“ (bls. 126). Kafli 16.8, Undanpága frá skyldunámi, lýsir svo undanpágu frá pessu: „Samkvæmt grunnskólalögum er skólastjóra heimilt ađ veita einstökum nemendum undanpágu frá skyldunámi í tiltekinni námsgrein ef gild rök mæla með pví. pá er t.d. átt við undanpágu nemenda með annað móđurmál en íslensku frá skyldunámi í dönsku“ (bls. 80).

2 The Programme for International Student Assessment (PISA) er alpjóđleg rannsókn sem gerð er á priggja ára fresti og hefur pað markmið að meta menntakerfi um allan heim međ pví að prófa hæfni og pekkingu 15 ára nemenda, sjá: https://www.oecd. org/pisa/ 


\section{HEIMILDIR}

Almar Halldórsson, Ragnar F. Ólafsson og Júlíus K. Björnsson. (2013). Helstu niðurstöđur PISA 2012: Læsi nemenda á stærđfræđi og náttúrufræđi og lesskilningur. Reykjavík: Námsmatsstofnun.

Anh-Dao Tran. (2007). Factors affecting Asian students' academic achievement in Iceland. Í Kristín Bjarnadóttir og Sigrún Klara Hannesdóttir (ritstjórar), pekking, pjálfun, proski: Greinar um uppeldis og fræđslumál, (bls. 191-213). Reykjavík: Delta Kappa Gamma.

Anh-Dao Tran og Hanna Ragnarsdóttir. (2013). Framtíđ í nýju landi: Próunarverkefni um innflytjendur í framhaldsskólum. Netla - Veftímarit um uppeldi og menntun. Sótt af http://netla.hi.is/greinar/2013/ryn/008.pdf

Anna Kristín Sigurđardóttir, Hafdís Guđjónsdóttir og Jóhanna Karlsdóttir. (2014). The development of a school for all in Iceland: Equality, threats and political conditions. Í U. Blossing, G. Imsen og L. Moss (ritstjórar), The Nordic education model: 'A school for all' encounters neo-liberal policy, (bls. 95-113). Dordrecht: Springer.

Anna Lilja Sævarsdóttir, Anna Elísa Hreiđarsdóttir og Hermína Gunnpórsdóttir. (2013). Foreldrasamstarf og fjölmenning: Samskipti deildarstjóra í leikskóla við erlenda foreldra sem ekki tala íslensku. Netla - Veftímarit um uppeldi og menntun. Sótt af http://netla.hi.is/greinar/2013/ryn/016.pdf

Anna Katarzyna Woźniczka og Robert Berman. (2011). Home language environment of Polish children in Iceland and their second-language academic achievement. Ráđstefnurit Netlu - Menntakvika 2011. Sótt af http://netla.hi.is/menntakvika2011/003.pdf

Banks, J. A. (2010). Multicultural education: Characteristics and goals. Í J. A. Banks og C. A. McGee Banks (ritstjórar), Multicultural Education: Issues and perspectives (7. útgáfa), (bls. 3-25). New York: Wiley.

Birgitta Birna Sigurðardóttir. (2012). „Pað væri gott ef kennarinn vissi meira ... “: Samskipti foreldra af erlendum uppruna viđ skóla barna sinna. Meistaraprófsritgerđ: Háskólinn á Akureyri, Hug- og félagsvísindasvið. Sótt af http://hdl.handle.net/1946/13093

Braun, V. og Clarke, V. (2006). Using thematic analysis in psychology. Qualitative Research in Psychology, 3(2), 77-101. https://doi.org/10.1191/1478088706qp063oa

Brown-Jeffy, S. og Cooper, J. E. (2011). Toward a conceptual framework of culturally relevant pedagogy: An overview of the conceptual and theoretical literature. Teacher Education Quarterly, 38(1), 65-84.

Bæck, U.-D. K. (2010). Parental involvement practices in formalized home-school cooperation. Scandinavian Journal of Educational Research, 54(6), 549-563. https://doi.org/10.1080/00313831.2010.522845

Creswell, J. W. (2007). Qualitative inquiry \& research design: Choosing among five approaches (2. útgáfa). Thousand Oaks: Sage.

De Fraja, G., Oliveira, O. og Zanchi, L. (2010). Must try harder: Evaluating the role of effort in educational attainment. The Review of Economics and Statistics, 92(3), 577-597. https://doi.org/10.1162/rest_a_00013

DePalma, R., Membiela, P. og Suárez Pazos, M. (2011). Teachers' memories of disciplinary control strategies from their own school days. British Journal of Sociology of Education, 32(1), 75-91. https://doi.org/10.1080/01425692.2011.532585 
Foucault, M. (1975). Surveiller et punir: Naissance de la prison. Paris: Gallimard.

Fuhui Chen og Hanna Ragnarsdóttir. (2014). Single-parent immigrant families in Iceland: Lives and educational experiences of their children. Netla - Veftímarit um uppeldi og menntun. Sótt af http://netla.hi.is/greinar/2014/ryn/006.pdf

Gay, G. (2000). Culturally responsive teaching: Theory, research, and practice. New York: Teachers College Press.

Gay, G. (2002). Preparing for culturally responsive teaching. Journal of Teacher Education, 53(2), 106-116. https://doi.org/10.1177/0022487102053002003

Hagstofa Íslands. (2016). Mannfjöldi eftir kyni, aldri, og sveitarfélögum 1998-2016. Sótt af http://px.hagstofa.is/pxis/pxweb/is/Ibuar/Ibuar_mannfjoldi_3_bakgrunnur Rikisfang/MAN04208.px/

Hagstofa Íslands. (2017). Grunnskólanemendur međ erlent móđurmál 1997-2016. Sótt af http://px.hagstofa.is/pxis/pxweb/is/Samfelag/Samfelag_skolamal__2 grunnskolastig__0_gsNemendur/SKO02103.px/

Hanna Ragnarsdóttir. (2008). Collisions and continuities: Ten immigrant families and their children in Icelandic society and schools. Saarbrucken: VDM.

Hanna Ragnarsdóttir. (2016). Námsrými félagslegs réttlætis og menntunar án ađgreiningar: Niðurstöđur norrænnar rannsóknar um velgengni nemenda af erlendum uppruna og skóla á fjórum Norđurlöndum. Netla - Veftímarit um uppeldi og menntun, Sérrit 2016 - Námsrými félagslegs réttlætis og menntunar án ađgreiningar. Sótt af: http://netla.hi.is/serrit/2016/namsrymi_felagslegs_rettlaetis_og_menntunar_an_ adgreiningar_learning_spaces_for_inclusion_and_social_justice/001.pdf

Hanna Ragnarsdóttir og Schmidt, C. (ritstjórar). (2014). Learning spaces for social justice: International perspectives on exemplary practices from preschool to secondary school. London: Institute of Education Press.

Hargreaves, A. (2000). Four ages of professionalism and professional learning. Teachers and Teaching, 6(2), 151-182. https://doi.org/10.1080/713698714

Hermína Gunnpórsdóttir og Ingólfur Ásgeir Jóhannesson. (2014). Additional workload or a part of the job? Icelandic teachers' discourse on inclusive education. International Journal of Inclusive Education, 18(6), 580-600. https://doi.org/10.1080/13603116.20 13.802027

Hulda Karen Daníelsdóttir, Ari Klængur Jónsson og Hilma Hólmfríđur Sigurđardóttir. (2010). Nemendur međ islensku sem annað tungumál i grunnskólum - upplifun fagfólks skólanna. Reykjavík: pjónustumiðstöđ Miðborgar og Hlíđa.

Ingólfur Ásgeir Jóhannesson, (2006). "Strong, independent, able to learn more...": Inclusion and the construction of school students in Iceland as diagnosable subjects. Discourse: Studies in the Cultural Politics of Education, 27(1), 103-119. https://dx.doi. org/10.1080/01596300500510328

Ingvar Sigurgeirsson, Amalía Björnsdóttir, Gunnhildur Óskarsdóttir og Kristín Jónsdóttir. (2014). Kennsluhættir. Í Gerður G. Óskarsdóttir (ritstjóri), Starfshættir í grunnskólum viđ upphaf 21. aldar (bls. 113-158). Reykjavík: Háskólaútgáfan.

Jóhanna Einarsdóttir. (2008). Children's and parent's perspectives on the purposes of playschool in Iceland. International Journal of Educational Research, 47(5), 283-291. https://doi.org/10.1016/j.ijer.2008.12.007 
Kozleski, E., Artiles, A. og Lacy, L. (2013). The dangerous politics of difference: How systems produce marginalization. Í L. C., Burrello, W. Sailor, og J. Kleinhammer-Tramill (ritstjórar), Unifying educational systems: Leadership and policy perspectives (bls. 217-229). New York: Routledge.

Kristín Ađalsteinsdóttir, Guðmundur Engilbertsson og Ragnheiður Gunnbjörnsdóttir. (2007). Fjölmenningarleg kennsla í Manitoba í Kanada, í Noregi og á Íslandi. Tímarit um menntarannsóknir, 4, 137-156.

Kvale, S. og Brinkmann, S. (2009). Interviews: Learning the craft of qualitative research interviewing (2. útgáfa). Thousand Oaks: SAGE.

Ladson-Billings, G. (1995). Toward a theory of culturally relevant pedagogy. American Educational Research Journal, 32(3), 465-491. https://doi.org/10.2307/1163320

Lareau, A. (1987). Social class differences in family-school relationships: The importance of cultural capital. Sociology of Education, 60(2), 73-85. https://doi.org/10.2307/2112583

Liebkind, K., Jasinskaja-Lahti, I. og Solheim, E. (2004). Cultural identity, perceived discrimination, and parental support as determinants of immigrants' school adjustments: Vietnamese youth in Finland. Journal of Adolescent Research, 19(6), 635-656. https://doi.org/10.1177/0743558404269279

Lög um grunnskóla nr. 91/2008.

Magdalena Zawodna. (2014). Menntun tvítyngdra barna i íslensku skólakerfi i ljósi skóla án aðgreiningar og fjölmenningarlegrar menntunar: Eigindleg rannsókn á viðhorfum foreldra tvítyngdra barn. Meistaraprófsritgerđ: Háskólinn á Akureyri, Hug- og félagsvísindasvið. Sótt af http://hdl.handle.net/1946/19128

McGee Banks, C. A. (2010). Communities, families, and educators working together for school improvement. Í J. A. Banks og C. A. McGee Banks (ritstjórar), Multicultural education: Issues and perspectives (7. útgáfa) (bls. 417-438). New York: Wiley.

Mennta- og menningarmálaráđuneyti. (2012a). Ađalnámskrá framhaldsskóla 2011: Almennur hluti. Reykjavík: Höfundur.

Mennta- og menningarmálaráđuneyti. (2012b). Ađalnámskrá grunnskóla 2011: Almennur hluti. Reykjavík: Höfundur.

Mennta- og menningarmálaráđuneyti. (2012c). Ađalnámskrá leikskóla 2011: Almennur hluti. Reykjavík: Höfundur.

Nichole Leigh Mosty, Samúel Lefever og Hanna Ragnarsdóttir. (2013). Parents' perspectives towards home language and bilingual development of preschool children. Netla Veftímarit um uppeldi og menntun, Sérrit 2013 - Rannsóknir og skólastarf. Sótt af http://netla.hi.is/serrit/2013/rannsoknir_og_skolastarf/006.pdf

Nína V. Magnúsdóttir. (2010). „Allir vilja eignast íslenskar vinir“: Hverjar eru helstu hindranir á vegi erlendra grunn- og framhaldsskólanemenda í íslensku skólakerfi? Meistaraprófsritgerđ: Háskóli Íslands, Menntavísindasvið. Sótt af: http://hdl.handle. net/1946/4576

OECD. (2010). Educating teachers for diversity: Meeting the challenge. París: Höfundur. Sótt af https://www.oecd.org/edu/ceri/educatingteachersfordiversitymeetingthe challenge.htm 
Ólöf Garðarsdóttir og Guðjón Hauksson. (2011). Ungir innflytjendur og ađrir einstaklingar með erlendan bakgrunn í íslensku samfélagi og íslenskum skólum 1996-2011. Rádstefnurit Netlu - Menntakvika 2011. Sótt af http://netla.hi.is/menntakvika2011/020. pdf

Reglugerđ um nemendur međ sérparfir í grunnskóla nr. 585/2010.

Rósa Guđbjartsdóttir og Hanna Ragnarsdóttir. (2010). Kennarar og kennarastarf í fjölmenningarlegu samfélagi: Raddir kennara innflytjendabarna. Tímarit um menntarannsóknir, 7, 77-92

Slee, R. (2006). Limits to and possibilities for educational reform. International Journal of Inclusive Education, 10(2-3), 109-119. https://doi.org/10.1080/13603110600578372

Sóley S. Bender. (2013). Samræđur í rýnihópum. Í Sigríđur Halldórsdóttir (ritstjóri), Handbók í ađferđafræđi rannsókna (bls. 299-312). Akureyri: Háskólinn á Akureyri.

Sólveig Karvelsdóttir og Hafdís Guđjónsdóttir. (2010). Raddir kennara sem kenna fjölbreyttum nemendahópum. Ráđstefnurit Netlu - Menntakvika 2010. Sótt af http:// netla.hi.is/menntakvika2010/022.pdf

UNESCO. (1994). The Salamanca statement and framework for action on special needs education. Paris: Höfundur.

Vaismoradi, M., Turunen, H. og Bonda, T. (2013). Content analysis and thematic analysis: Implications for conducting a qualitative descriptive study. Nursing \& Health Sciences 15(3), 398-405. https://doi.org/10.1111/nhs.12048

Villegas, A. M. og Lucas, T. (2002). Preparing culturally responsive teachers: Rethinking the curriculum. Journal of Teacher Education, 53(1), 20-32. https://doi. org/10.1177/0022487102053001003

Póroddur Bjarnason. (2006). Ađstæður íslenskra skólanema af erlendum uppruna. í úlfar Hauksson (ritstjóri), Rannsóknir í félagsvísindum VII: Félagsvísindadeild: Erindi flutt á ráđstefnu i október 2006 (bls. 391-400). Reykjavík: Félagsvísindastofnun Háskóla Íslands.

Póroddur Bjarnason. (2011). Framtíđarbúseta unglinga af erlendum uppruna. Ráđstefnurit Netlu - Menntakvika 2011. Sótt af http://netla.hi.is/menntakvika2011/032.pdf

Pórólfur Pórlindsson og Porlákur Karlsson. (2003). Um úrtök og úrtaksađferđir. í Sigríđur Halldórsdóttir og Kristján Kristjánsson (ritstjórar), Handbók í ađferđafræđi og rannsóknum í heilbrigđisvísindum (bls. 51-66). Akureyri: Háskólinn á Akureyri.

Greinin barst tímaritinu 8. mars 2017 og var sampykkt til birtingar 18. október 2017

\section{UM HÖFUNDANA}

Hermína Gunnpórsdóttir (hermina@unak.is) er dósent við Háskólann á Akureyri. Hún hefur BA-próf í íslensku og uppeldis- og kennslufræđi frá Háskóla Íslands, meistarapróf frá Kennaraháskóla Íslands (2003) og doktorspróf frá Háskóla Íslands (2014). Hún hefur starfað við leik-, grunn- og framhaldsskóla. Helstu viðfangsefni hennar í kennslu og rannsóknum eru skóli og nám án ađgreiningar, fjölmenning og nám, félagslegt réttlæti í menntun, fötlunarfræði, menntastefna og framkvæmd. 
Stéphanie Barillé (stephanie@unak.is) er rannsakandi við Háskólann á Akureyri og doktorsnemi við Háskóla Íslands. Hún hefur BA-próf í félagsfræđi og pjóđháttafræđi frá París VIII háskóla og meistarapróf frá École des hautes études en sciences sociales í París (EHESS). Helstu viđfangsefni hennar í rannsóknum eru málefni innflytjenda og velferđá Norðurlöndum.

Markus Meckl (markus@unak.is) er međ doktorspróf frá Tækniháskólanum í Berlín par sem hann stundađi nám við Miðstöð rannsókna um and-semítisma. Síđan 2004 hefur hann starfað við Háskólann á Akureyri og gegnir par starfi prófessors í fjölmiðlafræđi. Í rannsóknum sínum seinustu árin hefur hann einkum einblínt á innflytjendamál á Norđurlandi og birt fjölda greina um efnið. Hann tekur virkan pátt í verkefnum sem snúa að innflytjenda- og ađlögunarmálum á Norđurlöndunum og í Eystrasaltslöndunum og byggir par m.a. á víđtækri reynslu sinni af rannsóknarsamstarfi með Háskóla Lettlands í Riga og Lettnesku menningarakademíunni.

\section{Immigrant students: Parents' and teachers' experience of learning and teaching}

\section{ABSTRACT}

There is a constantly growing number of students of foreign origin in Icelandic education. These changes require schools and teachers to respond to the educational needs these students may have. The results of Icelandic research on multicultural education have, in the main, suggested that the Icelandic school system is failing in its efforts to educate children of foreign origin.

Current legislation on schools in Iceland strongly emphasises equality, and schools are expected to suit their operation as closely as possible to the situation and needs of the students; thus, in a broad sense, supporting every student's development, welfare and education. This emphasis is reiterated, at each stage, in the Icelandic National Curriculum Guide for Compulsory Schools (Mennta- og menningarmálaráđuneyti, 2012b) Icelandic education policy is based on the ideology of the inclusive school which focuses on meeting students' diverse needs, whether those be academic or social; thus the operation of the school attempts to ensure that students are given equal or equivalent educational opportunities

The policy also emphasizes the diversity of the student group, leading to their varied needs. Despite the attempt to recognize diversity within the Icelandic school system, for example in legislation and curricula, the multicultural aspect of the education policy has not received much attention.

In academic discourse on the inclusive school and multicultural education, research, 
both in Iceland and abroad shows that impediments to real change towards multicultural practices are not least to be found in attitudes to students who need additional assistance in their studies and in parents' and teachers' expectations towards them.

When initiating and developing a multicultural, inclusive school operation, respect for families and their diverse backgrounds has a crucial role. School staff have to be prepared to work with parents of varied origin and to demonstrate an understanding of their circumstances and world view. The objective of this article is to examine the experience of teachers and parents of students with immigrant background with regard to their education. Answers are sought to the following research questions: How do teachers approach the education of children of foreign origin; and how do parents from abroad perceive and experience their children's education?

Focus group interviews were conducted with thirty eight teachers from six primary schools discussing their experience of teaching students of a foreign background and the main challenges they faced in this context. Individual interviews were also conducted with ten parents from abroad in relation to their perception of Icelandic schools and their children's education,

The research revealed that the teachers feel they are not sufficiently trained and prepared to tackle the demanding tasks of multicultural teaching. Furthermore, the support and encouragement needed to stimulate teachers' interest and ambition to take on this kind of teaching appeared to be lacking. Due to insufficient communication between schools and homes, many parents are unfamiliar with the aims and methods of the Icelandic school system. This has caused foreign parents to distrust the school and prevented them from being able to keep close track of their children's studies. The parents' attitudes are coloured by their notions of the school as a traditional venue of study and the Icelandic school system challenges their traditional ideas in this respect. Cooperation and communication between parents and teachers is also lacking. The article suggests that these shortcomings should be dealt with and discussion and dialogue should be encouraged between the parties concerned, focusing on the students' needs and parental expectations, with the aim of supporting and improving the education of students of foreign origin.

Keywords: students with immigrant background, parents with immigrant background, multicultural education, collaboration between home and school

\section{ABOUT THE AUTHORS}

Hermina Gunnthorsdottir (hermina@unak.is) is associate professor at the University of Akureyri. She holds a BA-degree in Icelandic and a teaching certification from the University of Iceland, a Master's degree from Iceland University of Education (2003) and a Ph.D. from the University of Iceland (2014). She has worked at kindergarten, primary- and secondary schools. Her teaching and research interest is related to inclusive school and education, multicultarism and education, social justice in education, disability studies, educational policy and practice. 
Stéphanie Barillé (stephanie@unak.is) is a researcher at the University of Akureyri and a doctoral student in Anthropology at the University of Iceland. She holds a BA-degree in Sociology and ethnology from Paris VIII University and a Master's degree in Social Anthropology from the School for Advanced Studies in the Social Sciences (EHESS, France). Her current research focuses on the experiences of immigrants in the North of Iceland.

Markus Meckl (markus@unak.is) holds a Ph.D. from Berlin Technical University where he studied at the Center for Research on Anti-Semitism. Since 2004, he has been working at the University of Akureyri where he is a professor in media studies. In recent years, one of his research interests has focused on immigration issues in the North of Iceland from which a series of articles has been published. Drawing on a broad range of experience, including teaching at the University of Latvia and the Latvian Academy of Culture, he is involved in immigration and integration-related projects in the Nordic and Baltic countries. 